\title{
THE CONSTRUCTION OF THE VOTER IN FINLAND, C. 1860-1907
}

\section{Risto Alapuro}

The emergence of the modern voter, a constitutive element of representative democracy, is far from a trivial process. " It requires a widespread adoption of the electoral logic of equality based on the principle of "one individual, one opinion, one vote," a logic unfamiliar in the era preceding the establishment of mass politics. How this usually gradual and presumably laborious process, the construction of the voter, took place in Finland in the late nineteenth century and the beginning of the twentieth century is an interesting question: there, the electorate expanded and the political system underwent a sudden and thorough transformation in sharp distinction to the decadeslong development common in other countries. In a drastic reform in 1906 Finland's corporate system of representation was replaced by a unicameral assembly based on universal and equal suffrage for both men and women, and the number of qualified voters was multiplied tenfold. The scale of the change was unique in Europe. Yet, contrary to what one might presume, the transition occurred in a smooth and orderly fashion. In the first general elections in 1907 the turnout was 71 percent, and less than one percent of the ballots were rejected.

In an effort to explain this rapid success in the adoption of the democratic system of representation, I will first depict the ideal-typi-

* The first version of this paper was presented in the colloquium "Le vote obligatoire" in the Institut d'Études Politiques de Lille, 20-21 October, 2005. 
cal qualities of the modern voter. This will provide a frame of reference to assess the factors furthering or hampering the emergence of the voter in the Finnish case. Second, voting practices and conceptions of representation from the 1860s to the early years of the twentieth century will be examined in national and local politics and in associational activity. Finally, I will analyze the rapid transition in Finland from corporate representation to representation based on the individual and the extension of the vote from a narrow electorate to universal suffrage.

\section{The construction of the voter}

Ideally the development of the modern voter is a result of a long process of abstraction in which the citizen is increasingly detached from communal ties and becomes capable of forming an opinion autonomously. The voter, an "atom of the sovereign people" (Offerlé 1993, 53), is constructed in a continuous process of homogenization in which the development of the abstract individual, the voter, and the imposition of an abstraction, the law of the number, by the state, interact, one producing the other. This process - Michel Offerlé (1998, 41) calls it the "nationalization of the civic citizenship" - is a part of a larger process of imposing similar norms on the entire territory of the state and an indication of the capacity of the state to produce rational technologies of identification and standardized identities.

The construction of the voter is a constituent part of a representative democracy. But to create the voter is also to create the elected, and "the logic of political representation" is made manifest in eligibility (Abélès 1991, 262-263; also Offerlé 1998, 47).

This image, as idealized as it is, is useful as a yardstick in assessing the progress of the emergence of the voter in empirical cases. It effectively reminds us that the conceptual system characteristic of the modern voter does not emerge spontaneously. This system involves such principles as the same value for each vote and the secret ballot, respect for majority rule, and the voter who elects a candidate to represent him or her on the basis of an explicitly stated program (Offerlé 1993; Garrigou 1992). "It is indeed not self-evident to establish a connection between one's daily life and a piece of paper put in a box; it is not self-evident to learn to wait and to express one's grievances and hopes only in fixed and distant moments; it is not self-evident to limit this expression to the use of the ballot only; it is not self-evident to 
vote for somebody whom in many cases one has never seen" (Offerlé $1998,45)$. How did this process evolve in Finland?

\section{Corporate representation at the national level}

A basic starting point for reflection is that, unlike any other political entity in Europe, Finland preserved a corporate system of representation up to the beginning of the twentieth century. Developments preparing the ground for the individual and universalist principle of political participation did take place within this framework, but their role remained limited.

The main reason for the longevity and quasi-immutability of corporate representation lay in Finland's political status. From the Napoleonic wars until 1917 she belonged to the Russian empire as a Grand Duchy, but retained the institutions established in the preceding period, when the mainly Finnish-speaking regions east of the Gulf of Bothnia were a constituent part of Sweden. One of the most important of these was the four-chamber Diet. Nothing in its preservation (or reorganization in the framework of the new Grand Duchy) was very exceptional. Existing institutional structures of the annexed regions could well be co-opted by the autocracy, even though they differed from those prevailing in Russia. But at the same time these structures could not be easily reformed, and their capacity to function ultimately rested on a tenuous balance between the empire and the local elite. In Finland, the emperor, who was also the Grand Duke of Finland, did not convene the Diet until 1863, after having met with the assembled Finnish estates in the newly-conquered territory a half century earlier, in 1809. Subsequently, however, the Diet met at regular intervals, and in the last decades of the century its deliberations were accompanied by an intensifying political discussion and the rise of the Swedish- and Finnish-language press. Yet, as far as the autocracy remained unchallenged, no major readjustments in the nature of Finland's political representation could be expected.

In these circumstances, the Diet played an integral role in the formation of the Finnish state and in the building of the Finnish nation vis-à-vis the metropolitan country in the late nineteenth and early twentieth century. Given that, ultimately, local autonomy was based on the generosity of the emperor, not on formal recognition of fundamental laws going back to the Swedish period, the Estates became a key institution in the defense of what were perceived as irrevocably 
acquired constitutional guarantees for Finnish rights. The consolidation of Finland's distinctiveness remained a constant preoccupation of its political leaders, and the Diet was considered to be a cornerstone of its separate status. It tended to be seen as a symbol and manifestation of this status and of Finnish unity.

A peculiarity of Finland's system of representation was the presence in it of the freeholding peasants, along with the nobility, the occupational clergy, and the burghers. This was unique in nineteenthcentury Europe, indicating the existence of a strong peasantry that traditionally constituted the backbone of the social structure: the central landed class consisted of native freeholders. Not surprisingly, the proportion of the population belonging to the independent peasantry was by far the largest among the (social) estates. In 1890 it was 26.2 percent, whereas the corresponding figure for the burghers in the predominantly rural Finland was 3.1 percent, and for the nobility and the clergy 0.1 and 0.3 percent, respectively. ${ }^{1}$ In other words, more than 70 percent of the population was excluded from corporate representation. For purely quantitative reasons it is clear that only the election procedures in the Peasant Estate and possibly the Burgher Estate could gain broader importance in the construction of the modern voter under universal and equal suffrage.

Freeholders in the countryside were entitled to vote in the Peasant Estate; the number of votes at their disposal depended on the amount of land they owned. In a two-step procedure, the members in each commune first elected grand electors (often these were decided through negotiation), who then elected the representatives of the Peasant Estate in the Diet. In the Swedish period the grand electors were considered to be the spokesmen of the communes and were bound by the instructions of those who had nominated them. In the Diet Act of 1869, enacted only a few years after the resumption of the Diet in 1863, this element of the imperative mandate was eliminated, and the grand electors were allowed to vote according to their own convictions. But this small move toward the modern idea of representation was not accompanied by other reforms, e.g., the redefinition of the criteria of the qualified voters. Until 1905, their circle remained practically as narrow as it had been four decades earlier. In 1900 only 4.3 percent of the rural population was qualified voters. While their share of the adult population was of course considerably higher, those without the franchise formed the overwhelming majority, consisting notably of expanding groups of agrarian workers and tenant farmers. (Mylly 2006, 38-40.) 
Still, from a comparative perspective, the sheer existence of the Peasant Estate is an indication of the importance of popular groups in the history of political representation in Finland and in the Nordic countries more generally. It was of considerable significance in the development of the voting capacities needed and adopted in the elections of 1907.

Much more marked and directly significant for the subsequent developments were the reforms in the Burgher Estate and the public debate over the franchise in the towns. The Diet Act of 1869 and the constitutional amendment of 1879 eliminated the role of the burgher privileges by making the payment of taxes the criterion for granting the franchise in the towns. This was not only a modern feature in that it abandoned the corporate principle within the Estate by defining the electorate on the basis of quantitative economic criteria. It also implied that the elected members of the Estate represented, in principle, all inhabitants of the town (Mylly 2006, 41; cf. Pohjantammi $2003,385)$. In addition, it opened the door to the discussion of two other measures. The first focused on the criterion of taxation required for the franchise, which implied the possibility to lower or ultimately even to abandon the census - that is, to introduce universal suffrage. The second contemplated the reduction of the voting scale (i.e., the number of votes allotted to each voter). This ultimately implied the possibility to eliminate it as well, that is, to introduce equal suffrage. The discussion was animated by ambiguities in the mode of election and in decrees fixing the maximum number of votes per voter - all this toward the end of the nineteenth century when the towns were growing rapidly, especially their working-class populations.

In the 1880s the disagreements crystallized around the voting scale. At that time, the main nationalist grouping, the Finnish party, began to advocate granting a maximum of ten votes per voter in elections to the Burgher Estate. In 1881 a kind of electoral campaign was waged in several towns for the first time, including meetings, the publication of candidate lists in newspapers, and instances of test voting (ibid., 51). In the 1890s a movement was launched for equal (but not universal) suffrage in the Burgher Estate elections, now inspired by the left of the so-called Young Finns. They looked for support from the emerging worker movement. Soon thereafter, however, the worker movement organized nationally in 1899, adopted a Social Democratic program (in 1903), and separated itself from the tutelage of the Young Finns. At the same time it began a campaign for universal and equal suffrage for both men and women and for a unicameral 
assembly. During the first years of the twentieth century up to 1905, the extension of the franchise finally became a key issue in the Diet as well. Especially in 1904-1905 a number of electoral reforms surfaced in different party groupings and in different Estates. They included equal suffrage and, more vaguely, as an ultimate goal, universal suffrage at least for men, especially in the Burgher and the Peasant Estate. At the same time the worker movement gained more support in its campaign for a thorough electoral reform. (Mylly 2006, 66-79.)

The main phases of the franchise extension movement in the Burgher Estate testify to the increasing importance of the issue in the political debate toward the turn of the century. In the 1880s and the 1890s scattered initiatives were put forward in the Estate for equal and even universal suffrage, and demands for reform became more vocal with each passing year. One major theme in the discussion of institutional arrangements was the adoption of a bicameral parliament; this possibility was evoked for the first time already in the 1860s. However, it is important to note in the context of the making of the modern voter that the reform initiatives did not lead to any major readjustments in the system of representation by 1905. While the debate in towns started to mobilize popular groups beginning in the 1890s and the movement gained in importance in the beginning of the new century, the voting as a practice in national elections was limited to a narrow circle of people only.

\section{Representation of the whole people and representation of various groups}

Another dimension in the relation between popular groups and the political representation may be seen in the provision of the Diet Act of 1869 that the Estates "represent the People of Finland," a presumption to which the presence of the peasants in the Diet gave credibility. This conception was not uncommon in early nineteenth-century Europe (Kurunmäki 2003, 5), although it was incompatible with the republican conception deriving from the French Revolution - because the delegates or representatives received their mandate from their respective social estates, not from "abstract individuals." In late nineteenth-century Finland this view was undoubtedly reinforced by the central role of the "people" and of the "will of the people" in the nationalist ideology (see below). The rejection of the principle of the imperative mandate (pursuant to the Swedish Riksdag Act of 1810) 
was another manifestation of the idea that the Estates represent the entire population (Kurunmäki 2004, 3; Pohjantammi 2003, 376-377).

However, the prevailing conception of representation still retained a group-based aspect. In a sense it appeared, for example, in the view that the Burgher Estate represented all inhabitants of the towns (from 1879). It also predominated in many dissenting assessments, especially in the 1890s. All "parts of the people" or the "central actor groups" were to be represented in a reformed Diet. Another suggestion implied a functional view: not only should those be entitled to vote who were willing to pay taxes but also those individuals or groups whose work was "useful" (Pohjantammi 2003, 386, 387, 389). The representation of the (whole) people and the representation of the groups of which it was composed were not contradictory principles.

Finnish terminology seems to be compatible with the idea of coupling the representation of the entire population with the representation of its constituent parts (a hypothesis that gains additional support from the analysis of the associational activity; see below). The Finnish-language vocabulary was created in the nineteenth century as a step in the advancement of the language of the majority, Finnish, at the expense of the traditional language of the elites, Swedish. The Finnish word for "to represent", edustaa, is not derived from the Latin origin repraesentare, "to make present or manifest or to present again" (Pitkin 1967, 241), but from the image of standing or acting in front (edessä) of others, denoting originally those in a superior position in the church and the courts of justice but also an obligation and responsibility of those acting in front of and on behalf of others (edesvastuu). Later this verb appeared in reference to the activity of a solicitor or spokesman who presents the complaints of people, and of a delegate or representative of an Estate (edesvastaja, edesmies, edusmies, edustaja,...) (Pohjantammi 2003, 366-368). That is, the very words "to represent" (edustaa) and "representative" (edustaja) convey the idea of representing in the sense of "standing for" and "acting for" as well as the connotation of an authorization and the ensuing idea that the representatives are responsible to the voters (Pohjantammi 2003, 368-369; Pitkin 1967). The latter sense makes it natural to think of representation as an advancement of the interests of those being represented (cf. Pitkin 1967, 115-116). Likewise, the Finnish term for Parliament (eduskunta) is derived from the word denoting representation. Therefore it stresses the representation as "standing for" or 
"acting for," not as deliberation (see Pitkin 1967, 64), which meaning appears in the term "Parliament" (Palonen 2005). Moreover, in Finnish a Member of Parliament is a "Representative of the People" (kansanedustaja), which concretely expresses the view that the MP represents a whole, not particular groups (or parties). Both eduskunta and the term kansanedustaja emerged in the nineteenth century (Pohjantammi 2003, 369, 372-374), and were officially adopted in the parliamentary reform of 1906.

In sum, then, it may be hypothesized that the two themes of representing (partial) interests and of representing the whole people appear not only in the conceptualization of the Estates but also in the semantic layers of the Finnish terminology of representation.

\section{Voting and representation at the local level}

As stated above, the making of the modern voter entailed his or her disentanglement from communal ties. Therefore the local social structures and developments at the local level became crucial. Which kind of social and political structures existed in the Finnish localities in the late nineteenth century and how did they affect the construction of the voter?

One feature that stands out in comparison to the local institutions elsewhere in Europe was the Swedish-type tradition of strong self-administration. It was linked to a relative social homogeneity, or, to put it differently, to the peasant freeholders' central position as the landowner class. Up to the second half of the nineteenth century the main local administrative units were the Lutheran parishes, in which ministers headed the meetings attended by local freeholders whose consent was needed in matters concerning them, especially in decisions concerning various communal expenses. Participation in parish meetings could also be replaced by smaller assemblies representing the landowners, or the representatives in parish meetings could be elected by villages. The principles of representation differed from those of a modern democracy. If it so happened that all those concerned were not consulted, the role of the representatives could be assigned to "the most prestigious members of the community" or, in the towns, to "the most eminent burghers" (Soikkanen 1966, 10, 23, 26). Also, the norm that decisions must be taken unanimously lost its force only gradually as was also the case with the principle that those 
absent were not bound by the decisions made (which in a number of cases led to the obligation for those concerned to be present in the meetings).

In the last decades of the nineteenth century the growing economic prosperity of freeholders and an administrative reform reinforced their local position as the same time as they prevailed nationally in the Diet. In 1865 a Finnish reform of local self-government separated the municipal administration from the local parish administration and instituted a two- or three-tier system, consisting of a communal meeting, which could elect a communal council as a smaller assembly to make decisions, and a communal board as an executive organ. The participation in the communal meetings and in the election of the communal council was based on the amount of taxes paid, in practice on the extent of landownership, which soon assured the landowning peasants a predominant administrative position. Similar developments took place in the towns whose municipal self-government was reformed in 1873. Now the local administration both in the towns and the countryside was unambiguously based on personal wealth; the same was true at the national level in elections to the Burgher Estate and the Peasant Estate. Thus a unified system of representation established itself both in the rural and the urban municipalities, based unequivocally on the census.

The communal ties, from which the citizens had to be severed in order for the modern voter to emerge, seem to have been less constraining in Finland than in many other European states of the period, especially outside the Nordic countries. The contrast is striking if Finland is compared to such an established and centralized state as France, where local social inequalities were more marked and more deeply entrenched than in Scandinavia. There the local structures standing in the way of the making of the voter were linked above all to the catholic elites and the notables. For much of the nineteenth century voting in France was rooted in the local networks of power and influence. Before becoming "political," the voting results long registered local relations of domination and local loyalties: allegedly their memory is still very much alive (Garrigou 1992, 205-225; Abélès 1991, 16).

In the reforms of the Finnish local administration in 1865 and 1873 the franchise was given to groups that had little risk of falling prey to clientelistic or other forms of pervasive dependence. On the contrary, these groups, notably the landowning peasants, constituted a prospering and an increasingly self-conscious popular class. 


\section{Associations and representation}

All reforms and debates of the late nineteenth century notwithstanding - the municipal reforms locally and the franchise discussion nationally - the factual political participation remained closed to the overwhelming majority of the population until the twentieth century. ${ }^{2}$ But there is one sphere of activity that arguably served as a school for the future voters and therefore constitutes a crucial component in explaining the successful changeover to the wholly democratic system of representation in 1906-1907. The sphere of associational activity was important in all Nordic countries but nowhere became its significance as manifest as in the sudden and spectacular transformation of the political system in Finland.

Voluntary associations, a form of realization of the "law of the numbers" (Offerlé 1998, 46), are, at least ideally, based on individual and noncompulsory membership and are therefore expressions of development supplanting traditional forms of organization (Anheier $2001,2)$. To form an association is to organize on formally equal terms to promote a common purpose. To cite one of the best-known proponents of these organizations, internally associations - again ideally - instill "in their members habits of cooperation (...) and public-spiritedness," and externally they, or a dense network of them, enhance "interest articulation" and "interest aggregation" (Putnam 1993, 8990). Therefore they are, in this view, closely related to the principle of the representative democracy.

In Finland, peasants and other middle-class groups began to organize on a large scale in the late nineteenth century. This process was not harassed by the authorities; the right to organize into associations, including trade unions that initiated strikes, never became a matter of serious controversy. The most prominent organizations were the temperance movement, the youth associations, and the emerging worker movement - which were called "progressive societies" (edistysseurat [Liikanen 1995, 328]) - and the cooperatives. Importantly, the intermediate and intermediary organizational level was not established in opposition to the state but with the cooperation of the state-building and state-bearing intelligentsia. ${ }^{3}$

The proliferation of such associations was greatly reinforced by their close connection to the local administrative structures; a considerable part of their activities evolved from them. In Finland the associations had often close ties with the administration through the role of local civil servants (priests, teachers, etc.) and even through a 
partial fusion of the reformed local administration and the new voluntary associations. "Cooperation between the municipal administration and the voluntary organizations was more than cooperation only (...). Many voluntary organizations came into being by a decision in the local administration." "In the communally-oriented (kommunalistisk) spirit, both the civil servants and the ordinary people had to participate jointly in the activities of the associations, directly related to the official decision-making." (Stenius 1987, 283, 309.)

Moreover, the associational life greatly contributed to the legitimation of the "will of the people" as a principle of politics: in the nineteenth century "the 'will of the people" was established as a basic concept in political language through associational activity and meetings" (Liikanen 1995, 329). The central issue at the end of the century as to whether organizations had "the right (...) to represent the 'will of the people"," led to a "tradition in the Finnish political culture, in which the organizations of the civil society had a strong legitimacy (...) as representatives of the 'will of the people' vis-à-vis the state power" (ibid., 332). This means that the language of modern politics - or the language of representation, of the right to represent the "people" - was adopted in Finland before the adoption of universal suffrage. Especially the temperance associations, the agrarian youth societies and the worker organizations were considered to be legitimate representatives of more or less identifiable social groups.

The latter aspect seems significant: associations were instrumental in defining (social) groups. A process took place in which the image of a nation emerged consisting of distinct, organized groups. That there is nothing self-evident in this image becomes clear if Finland is contrasted to France, admittedly an extreme example. There, as Pierre Rosanvallon $(1998,330)$ puts it, the "Republic rendered the social abstract," leaving the field open to a mode of representation whose special character lay in operating with no a priori references. In this view, associations could be considered "artificial" and in any case not as legitimate representatives of group interests. In the case of Finland they were arguably instrumental in establishing the legitimacy of the group representation, which appeared alongside the equally legitimate conception of the representation of the "will of the [whole] people." It seems worth examining, whether, or to what extent, this duality has parallels with the different semantic layers of the Finnish terminology of representation referred to above. 


\section{The radical franchise reform of 1905-1907}

That the proliferation of the voluntary associations prepared the way for electoral politics is dramatically shown by the events in Finland in 1905-1907. At the end of October 1905 the revolutionary situation in Russia extended into Finland, provoking a general strike there as well. In Finland the collective action crystallized in demands for the reversal of the Russian attempts to integrate Finland into the empire and to reform the political system entirely. Both demands were supported by all major political tendencies, but the Social Democrats were the most vocal in this. A relatively modest force until then, they now took the lead in a large-scale mobilization and suddenly emerged as a major political movement. With unprecedented force the party advocated its foremost concrete objective, the introduction of the unicameral assembly based on universal and equal suffrage for both men and women. The Social Democrats were followed by nonsocialist groups, whose leaders had until then been generally satisfied with less radical changes (preferring a two-chamber system, the limitation of the suffrage to men, equal but not universal suffrage, etc.). (See Mylly 2006, 112-118.)

In the revolutionary situation then prevailing in Russia, and under the pressure of large-scale protests in the minority regions, the emperor considered it necessary to consent to the demands in Finland, and promptly authorized (in early November 1905) the transformation of the political system along the lines championed by the mass movement. The new system was confirmed the following year by the Estates, under pressure from the socialist-led demonstrations, declaring the "will of the people" as the supreme value. The Estates were indeed replaced by a unicameral assembly based on universal and equal suffrage for both men and women. Until then, unicameral legislatures existed only in a few Balkan countries, and female suffrage nowhere in Europe (Törnudd 1968, 30).

Finland thus experienced a reform in which Europe's most conservative estate-based Parliament was superseded by the most democratic system of representation in the whole Continent. The great leap from the corporate conception of representation to one based on the individual was made all at once. The Russian autocracy had guaranteed the quasi-immutability of an antiquated system of representation. Now its temporary collapse led in one stroke to a fully democratic electoral system. The reform multiplied tenfold the num- 
ber of qualified voters from 126,000 to $1,273,000$. It is true that there was a major constraint: the final decision on legislation remained in the hands of the emperor. But this is not of primary importance if the reform is considered from the point of the creation of the modern voter.

The most important single reason for the remarkably easy accomplishment of the transformation lay in the nature of the general strike as the powerful vehicle of national mobilization and manifestation vis-à-vis Russia. The extension of the electorate, which was seen by the Social Democrats as the extension of the influence of the popular masses, was seen by all groups as a reconfirmation of Finland's autonomous position after the Russian integration measures in the previous years. "It was widely felt that a legislature with broad popular support could best stand up against Russia and assert both the rights and the will of the people of Finland" (Törnudd 1968, 28). Furthermore, a belief in the ultimate solidarity of the people, a faith in the "peasant folk" also generally prevailed in the non-socialist parties. This belief helped to make the radical reform acceptable or even desirable to them, especially at the local level. Solidarity between the (Finnish-speaking) people and the (Finnish-speaking) educated class constituted a cornerstone in the nineteenth-century national movement.

A highly urgent reason for pushing the reform through was the common perception that it should be concluded before the Russian autocracy recovered from its momentary weakness: there was little time for internal dissension. This need was felt most intensely in the Reform Committee that was preparing the new legislation in the end of 1905 and in 1906; all of the main political groups, including the Social Democrats, were represented in it (see Mylly 2006, 105-109). Under this pressure and in the wake of an enormous wave of mobilization, granting the suffrage to women provoked practically no opposition. Women had a comparatively egalitarian status with men in the peasant society, and as a corollary to it they had played an active role in the organized popular movements of the nineteenth century (Sulkunen 1997). In addition, given the narrow social base of the Diet, the reform came to be defined as a suffrage issue, not as a gender issue, as was the case wherever extensive male suffrage was established early (Koskinen 1997, 29).

The adopted electoral system was based on proportionality - a principle in use nationally at that time only in Belgium, Serbia, and Denmark for elections to the upper chamber (Törnudd 1968, 30). In 
the short term, this decision stemmed from the perceived need of nonsocialists, and above all of the Swedish party, to protect the right of minorities (not only those of the Swedish-speaking minority but also, for example, of those having a higher education) (Mylly 2006, 166194). However, it was also in line with the long-term view of the representation and the nature of the mobilization itself. As stated above, the population of Finland was seen as consisting of distinct groups, a conception reinforced by the construction work accomplished by organized popular movements. This view prevailed in the adoption of proportional representation. Its "primary and explicit motivation" was "mirroring the whole people" (Törnudd 1968, 13), which emphatically meant that the representation should cover all the various social groups - "all citizen circles" (kansalaispiirit) (Seitkari 1958, 133), "all ideological groups," "all the social conditions and demands" of the nation (Constitutional Committee in 1906, cited in Kurunmäki 2005, 123 and 125, respectively). Parliament was supposed to constitute a "miniature (pienoiskuva) of the people of Finland" (Teljo 1949, 71).

The people, consisting of different groups, were not seen only as their sum total. The strong rhetorical force of the "people" and the "will of the people" implied a totality that was composed of different parts in mutual solidarity. After the reform, according to P. E. Svinhufvud, a leading figure of the Young Finnish party, "Parliament will represent all strata of the people; then our people as a whole will stand as a support for our Parliament" (cited in Seitkari 1958, 125). The meaning of the representation of groups and strata did not differ from the meaning of the "representation of the whole people" (Pohjantammi 2003, 394). According to the Parliament Act confirmed in 1906, Parliament "represents the people of Finland," as the Estates had done according to the Diet Act of 1869.

All three arguments - the representation of the people as a whole and in its diversity and the protection of the minority rights - appear in the motivation the Diet Reform Committee gave to a system of proportional representation (cited in Törnudd 1968, 33):

The representation should ... give a picture of the people as a whole, expressing the various pursuits and interests that are prominent within it. In countries having an external power position, the main stress can be put on having a numerically strong majority in the popular representation; with us, on the other hand, it is above all important that all are included, thus not preventing smaller opinion groups from participation in the representation and its work. 
The fact that different dimensions are visible in the reform implies a peculiar mixture of unity and plurality. On the one hand there was a strong "rhetoric of entirety and unity" that did not imply active participation: "The universal and equal suffrage in Finland was, foremost, a matter of including all 'members of the society' in the political nation. It was not intended to make them any more politically active" (Kurunmäki 2005, 123, 124). Indeed, as stated above, "Parliament" in Finnish became "House of Representatives" (eduskunta), and "Member of Parliament" became a "Representative of the People" (kansanedustaja) - two Finnish terms that convey no special emphasis on the deliberative aspect of democracy. Perhaps it is no accident that in comparative Nordic studies that try to make sense of the low turnout in the present-day elections, precisely the weak political discussion culture has been found to be a specifically Finnish explanatory factor (Kom.miet. 2005:1, 19).

On the other hand, plurality is in evidence, in the proportional representation and in the high degree of stability of the emerging party system. The contours of the party support in 1907 can be clearly discerned in the Finnish parliament even today. In all essentials it came to resemble the party systems in the other Nordic countries, in which democratization was a longer process but which socio-structurally resembled Finland. The contrast is striking again with France, where proportionality has gained ground only partially and laboriously and where the party system is less established and the representation of economic and social interests less institutionalized than in many other countries. Pierre Rosanvallon $(1998,310,313)$ links this feature to the persistence of revolutionary monism in France until the Fifth Republic, with its abstract approach to representation. It has much less structuring capacity than the Finnish approach to representation.

\section{The construction of the voter in 1905-1907}

The electoral reform was not only accepted without difficulty; it was also carried out smoothly. In the first general elections in 1907 the turnout was 71 percent. The election itself took place "in complete calm and without any kind of disorder," and the voters knew how to cast their votes: less than one percent of the ballots were rejected (Tuominen 1958, 172). Even the enormous wave of popular mobilization in 1905 prior to the election had occurred mainly in an orderly 
fashion, despite large-scale demonstrations and a great number of local mass meetings. There were nothing comparable to the repercussions of the same crisis in the Baltic provinces of Russia: there the paralysis of the autocracy in 1905 launched jacqueries in which nobles were killed, manors burned, records destroyed, churches sacked. In Finland the predominant objective was securing an essential aspect of the orderly conduct of political life, namely the right to vote. Enthusiasm and high expectations were crystallized in it rather than in violent direct action. "If the franchise is granted, there is no risk of anarchy even in conditions of tension," remarked a Social Democratic leader in the end of 1905 (Yrjö Sirola, quoted in Seitkari 1958, 50).

The most characteristic feature in the appropriation of the new system of representation was the large-scale organization process that accompanied it. This process was most spectacular under the umbrella of the Social Democratic party. In 1907 the Social Democrats gained more than one-third of the vote, exceeding not only the expectations of others but in part even their own estimations. With 80 of the 200 seats in Parliament, they became the largest socialist party in Europe. This result was preceded by an extraordinary wave of organization. The number of the dues-paying members in the party rose from 16,000 in early 1905 to 107,000 in October 1906. In the mobilized atmosphere of 1905, the process began from below. A movement that until then had gathered members primarily from towns and other centers was extended to the agrarian milieu, including remote villages. New workers' associations were founded so widely and their ranks swelled so rapidly that the party was overwhelmed and was temporarily at pains to control the process.

To take an example, in the South-Western agrarian commune of Huittinen, where by 1905 local artisans had come to dominate the numerically modest workers' association, eight new associations were founded in the course of one year, and the membership rose overnight from 50-60 to 550, about 15 percent of the workforce in the commune. All of the new associations were formed in the agrarian milieu, in villages surrounding the center, and in all of them both the leaders and the other members were primarily engaged in agrarian occupations. In the election of 1907 the turnout in the commune rose to 79 percent. The Social Democrats received 57 percent of the vote (typical in the region as a whole), and in subsequent elections they consolidated their position. (Alapuro 1994, 99-105; Alapuro 1998, 7476.) 
It is true that strictly speaking the wave of organization turned out to be temporary. The figures dropped in the following years. However, the associations themselves remained, and the workers' halls as their central sites retained a pivotal role in gathering common folk for various cultural and political activities. The increase in number of halls in the country from 47 in 1905 to 940 in 1916 is very clearly reflected in Huittinen as well.

This summary makes the point that the thorough electoral reform was accompanied by a large-scale process of political organization that supported the making of the voter. This is true not only of the worker movement, even if it is the most spectacular case. In other, more well-to-do groups the process had gained ground earlier, and now it also intensified, serving as a starting point for local party sections. These sections usually remained less significant than their background organizations and had a lower profile than the workers' associations (Mylly 2006, 263-284). Huittinen provides again an example. There, the big mass meetings of the fall of 1905 were run by leading personalities from all organized groups, all calling for universal, equal, and direct suffrage for men and women and a unicameral assembly. Despite hesitation or unwillingness at the national level, local non-socialists commonly joined this chorus all over Finland in the fall of 1905 (cf. Seitkari 1958, 46). The largest and most highly charged meeting in Huittinen was presided over by the director of the local educational institute for the peasants' offspring (kansanopisto). This man was active in the youth association and had served as the chairman of the local farmer society. The post of secretary in the meeting was held by an elementary school teacher who had a leading position in the cooperative store, the savings bank, the youth association, the temperance society, and, a little later, when the preparations for the elections of 1907 gained momentum, in the newly founded local section of the Finnish party (the main non-socialist party). One of the other main organizers was an artisan who led the workers' association and the voluntary fire brigade, which were closely connected to each other. (Alapuro 1994, 95-96.)

The suffrage issue provoked not only mass meetings in the commune but also led to the founding of the Discussion Circle of Huittinen in December 1905. In it, people who until then had met in the associational and communal life met for the first time as representatives of various political parties - the Social Democratic party, the Finnish party, and the so-called Constitutionalists (later the Young Finnish party) (ibid., 98-99). The Circle turned out to be short-lived; it was 
dissolved when the new electoral system was approved in 1906 and the local sections of the Finnish party and the Young Finnish party were founded in the commune. Nevertheless, its short history shows how the deliberation and adoption of political programs arose from the sphere of the earlier popular organization in the commune. People who knew each other well met now in a new forum in which local issues were simultaneously fused with issues of national politics.

All this said, the making of the voter in Finland of 1905-1907 was certainly characterized by many deficiencies and contradictions as well. This process, which occurred in a sudden act of mobilization, even aided by previous groundwork, could not fail to mark the appropriation of the procedures of representative democracy. The character of the crisis of 1905 as a "moment of madness" is important here. This is what Aristide R. Zolberg calls moments of political enthusiasm or exaltation, when "all is possible" $(1972,184)$. "Liberated from the constraints of time, place, and circumstance, from history, men choose their parts from the available repertory or forge new ones in an act of creation. Dreams become possibilities" (ibid., 196). New ideas "emerge as widely shared beliefs among much larger publics... these new beliefs expressed in new language are anchored in new networks of relationships which are rapidly constituted..." (ibid., 206).

In these situations politics disappears as a separate sphere of human action. It seems to merge into civil society, and the political function no longer exists as a specialized function (ibid., 190). Something similar seems to have pervaded the popular understanding of the vote and the casting of a ballot in Finland in 1905-1907. In the Social Democratic rhetoric "the election [of 1907] was portrayed as a 'crossing' after which events would take a completely new direction. If the Social Democrats were successful, a completely new era would dawn. Then the 'gospel of socialism' and the 'pure light of socialism' would transform all ... evil, notably the evil adhering to the capitalist society, into good" (Soikkanen 1961, 357). This is how a Social Democratic newspaper exhorted people to vote: "Working man, working woman! Your weapon is new, but it is invincible. It will prevail. Wield it with vim and vigor..." (cited in ibid., 363).

Undoubtedly an evangelical tinge can be found elsewhere as well in early socialist movements. But in Finland it was strongly attached to the vote, thanks to the linkage of the upsurge of socialism with a radical extension of political rights. The belief in the ballot in 1907 is expressed in a pronounced way in Punainen viiva (The Red Line), 
Ilmari Kianto's famous novel published in 1909. The title refers to the act of voting. If the voter accepted one of the three-candidate lists in the order proposed by parties, (s)he indicated this on the very large ballot paper by drawing a red line on the upper-hand corner of the list chosen (on the electoral system, see Törnudd 1968, 35-40). The novel describes the casting of the ballot as the culmination of a quasireligious conversion in the life of a poor cottager and his wife (in the absence of an English translation, a couple of passages from the German edition [1920, 107, 110, 116, respectively]):

Heute war der glühendheisse Tag des roten Strichs!

Heute war der erste Tag der Neugeburt des Landes!

Heute, heute war der schwere, schwere Tag der geistigen Feldschlacht!

Topi schneuzte sich wie zur Feier des Tages und blickte von unten herauf achtungsvoll auf allen diejenigen, die den roten Strich schon glücklich erledigt hatten. Sie erschienen ihm wie Heilige, denn jeder von ihnen wusste mehr Geheimnisse, als ein gewöhnlicher Bauernklotz aus der Einöde weiss. Sie waren gewissermassen durch das Tor des Todes geschritten...

Topi starrte auf die Umrahmung, deren Nummer ihm eingeprägt worden und die, wie er wusste, für das Proletariat bestimmt war. "Dreissig und ... Zollizahlrat!" ...

"Das sind die letzten Lockungen des Seelenfeinds..." schoss es ihm durch den Kopf, und die Stirn runzelnd, den Blick stählend begann er mit beiden Händen zu suchen.

"Dreissig und ... Zollizahlrat."

"Teufel! jetzt kommst du mir nicht wieder aus den Klauen!"

Er stiess den Daumen der linken Hand fest auf die Nummer und nahm mit der rechten wieder den Bleistift. Vorsichtig, den Atem anhaltend, begann er eine dünne Linie zu malen...

Indeed, the casting of the ballot was far from self-evident to many of those who were now entitled to vote. One indication is that in many localities a kind of election exercise was conducted before the election in March 1907 (cf. Tuominen 1958, 171; Hako et al. [eds.] 1964, 160-161). In Huittinen such a rehearsal was held in the fall of 1906, with labels of different parties. At least one workers' association organized an exercise of its own before the election day. But although these events reflect the unfamiliarity of many Finns with elections, they also speak of their willingness and preparedness to master the election procedures and carry them out in an orderly fashion. More- 
over, they tell of the latitude people had to "draw the red line" without dependence on the local power relations, and what is perhaps most important of all, of the widespread ability of ordinary people "to establish a connection between one's daily life and a piece of paper put in a box," "to limit the expression of grievances to the use of the ballot only," and "to vote for somebody whom in many cases one has never seen."

It seems fair to say that all deficiencies notwithstanding, the election of 1907 was a considerable manifestation of individual-based political equality. Many people were dressed in their best clothes (Nousiainen 2006, 18). A newspaper description of voting in the center of Huittinen in 1910 stresses the dignity of the act and the independence of the voter (cited in Viikki 1989, 625-626):

Solemnly people walked up to the ballot box, as if they were entering the church. A prayer undoubtedly arose in many hearts that the Lord would guide them to make a wise choice, because presumably no such scoundrel exists who, in stepping up to the ballot box, would contemplate the ruin of the country and his/her [own] people.

\section{Finland in a comparative perspective}

Above, a few comparative remarks have related circumstances that attended the making of the voter in Finland to those in France and in other Nordic countries. The contrast provided by France reminds us that the construction of the voter is no trivial process and that it appears to have occurred in Finland in an extraordinarily smooth way, especially when we take into the account how abruptly the political arena opened in 1905-1907. It is indeed one thing that the voter is more or less gradually "made" by the electoral process, as happened in France (Garrigou 1992, 18), and quite another that previous associational and communal activity creates a "proto-voter" who is able to play the role when the electoral arena opens up, as happened in Finland. It is significant that it took long time before specifically political organizations appeared in France at the local level and even today the politically relevant "networks ... as is usual in rural milieux ... do not have the consistency of a structured organisation" (Agulhon 1981; Abélès 1991, 18 [quote]).

With the other Nordic countries, in contrast, Finland shares a fundamental similarity of social and institutional structures. What 
separated her from her Scandinavian neighbors was the persistence of an obsolete system of representation and its sudden elimination in favor of universal suffrage. The difference stems from Finland's profound dependence on a power center outside its borders, which made her subject to its vicissitudes in a way that were unknown in the other Nordic countries. Under these circumstances, the preparedness of Finns to take the role of the voter without an extensive period of training in the political institutions proper is striking in comparison to the Scandinavian countries where the introduction of representative democracy was a more gradual process and the associational activity was consequently gradually intertwined with it over the course of many decades. This is pronounced in Sweden, where the popular movements, folkrörelser, played a central role in democratization itself in the nineteenth century, and then had an enormously strong presence in the Swedish Parliament.

In a broader perspective, however, the similarity between Finland and her Scandinavian neighbors is very clear. The proportional principle prevailed, and the party systems that emerged in the early twentieth century were similar in Sweden, Denmark, Norway, and Finland. ${ }^{4}$ The resemblance testifies to the weight of their social structural and institutional similarity and the importance of the ensuing similarities in the early stages of popular organization, despite differences in timing. The abrupt transformation that Finland experienced could not prevent her from paralleling them in these respects.

\section{NOTES}

1. At the beginning of the twentieth century the composition of the Nobility in the Diet depended on 850 nobles, and the number of those entitled to vote in the Clergy amounted to 950 (Teljo 1949, 40).

2. In this section I have drawn from an earlier text (Alapuro 2005).

3. For a concise summary of this line of thought, see Stenius 1983, 112.

4. In the formation period the most noteworthy exceptions were the absence of a purely agrarian party in Denmark and the existence of the small Swedish party in Finland (Mylly 1980, 277-289). 


\section{REFERENCES}

Abélès, Marc 1991. Quiet Days in Burgundy: A Study of Local Politics. Cambridge: Cambridge University Press.

Agulhon, Maurice 1981. Les associations depuis le début du XIXe siècle. In Maurice Agulhon \& Maryvonne Bodiguel, Les associations au village. Le Paradou: Actes Sud, 9-38.

Alapuro, Risto 1994. Suomen synty paikallisena ilmiönä 1890-1933. Helsinki: Hanki ja jää.

Alapuro, Risto 1998. Artisans and Revolution in a Finnish Country Town. In Michael P. Hanagan, Leslie Page Moch \& Wayne te Brake (eds.), Challenging Authority: The Historical Study of Contentious Politics. Minneapolis: University of Minnesota Press, 73-88.

Alapuro, Risto 2005. Associations and Contention in France and Finland: Constructing the Society and Describing the Society. Scandinavian Political Studies 28, 377-399.

Anheier, Helmut K. 2001. Sociology of Voluntary Associations. International Encyclopedia of the Social \& Behavioral Sciences. Elsevier Science Ltd.

Garrigou, Alain 1992. Le vote et la vertu. Comment les Français sont devenus électeurs. Paris: Presses de la Fondation Nationale des Sciences Politiques.

Hako, Matti, Heimo Huhtanen \& Matti Nieminen (eds.) 1964. Aatteet ja vaatteet. Helsinki. Tammi.

Kianto, Ilmari 1920 [1909]. Der rote Strich. Dresden und Leipzig: Verlag von Heinrich Minden. Translated from Finnish by Gustav Schmidt.

Komiteanmietintö 2005:1. Edustuksellinen demokratia. Kansanvalta 2007 -toimikunnan mietintö.

Koskinen, Pirkko K. 1997. Äänioikeuden lainsäädäntöhistoriaa. In Eeva Ahtisaari et al., Yksi kamari - kaksi sukupuolta. Suomen eduskunnan ensimmäiset naiset. Helsinki: Eduskunnan kirjasto, 26-41.

Kurunmäki, Jussi 2003. The Formation of a Representative Politial System in Finland, 1809-1863. Paper prepared for the workshop The Formation of Representative Democracy. ESF Network The Politics and History of European Democratisation, University of Málaga, 10-11 October.

Kurunmäki, Jussi 2004. From Political Estates to Unicameral Democratic Parliament: Finland 1905-1906. Paper prepared for the workshop Democratisation and Political Rhetoric. ESF Network The Politics and History of European Democratisation, University of Jyväskylä, Finland, 28-29 May.

Kurunmäki, Jussi 2005. A Parliament for the Unity of the People: On the Rhetoric of Legitimisation in the Debate over Finnish Parliamentary Reform in 1906. In Lars-Folke Landgrén \& Pirkko Hautamäki (eds.), People, Citizen, Nation. Helsinki: Renvall Institute, 116-131.

Liikanen, Ilkka 1995. Fennomania ja kansa. Joukkojärjestäytymisen läpimurto ja Suomalaisen puolueen synty (with an English summary 'Fennomania and the People: The Breakthrough of Mass Organization and the Birth of the Finnish Party'). Helsinki: Suomen Historiallinen Seura. 
Mylly, Juhani 1980. The Emergence of the Finnish Multi-party System: A Comparison with Developments in Scandinavia, 1870-1920. Scandinavian Journal of History 5, 277-293.

Mylly, Juhani 2006. Edustuksellisen kansanvallan läpimurto. Helsinki: Edita. Suomen Eduskunta 100 vuotta 1.

Nousiainen, Jaakko 2006. Keisarin alamaisista toimiviksi kansalaisiksi. In Miia Pesonen \& Harri Westermarck (eds.), Studia Generalia 2006 - Eduskunta 100 vuotta - Demokratian haasteet. Helsinki: Yliopistopaino, 11-22.

Offerlé, Michel 1993. Un homme, une voix? Histoire du suffrage universel. Paris: Gallimard.

Offerlé, Michel 1998. La nationalisation de la citoyenneté civique en France à la fin du XIXe siècle. In Raffaele Romanelli (ed.), How Did They Become Voters? The History of Franchise in Modern European Representation. New York: Aspen Publishers, 37-51.

Palonen, Kari 2005. Eduskunnasta puhekunnaksi? Parlamentarismi retorisena politiikkana. Politiikka 47, 142-148.

Pitkin, Hanna Fenichel 1967. The Concept of Representation. Berkeley: University of California Press.

Pohjantammi, Ismo 2003. Edustus. In Matti Hyvärinen et al. (eds.), Käsitteet liikkeessä. Suomen poliittisen kulttuurin käsitehistoria. Tampere: Vastapaino, 363-412.

Putnam, Robert D. 1993. Making Democracy Work: Civic Traditions in Modern Italy. Princeton: Princeton University Press.

Rosanvallon, Pierre 1998. Le peuple introuvable. Histoire de la représentation démocratique en France. Paris: Gallimard.

Seitkari, Olavi 1958. Edustuslaitoksen uudistus 1906. In Suomen kansanedustuslaitoksen historia, vol. 5. Helsinki: Eduskunnan historiakomitea, 7-162.

Soikkanen, Hannu 1961. Sosialismin tulo Suomeen. Ensimmäisiin yksikamarisen eduskunnan vaaleihin asti. Porvoo and Helsinki: WSOY.

Soikkanen, Hannu 1966. Kunnallinen itsehallinto kansanvallan perusta. Maalaiskuntien itsehallinnon historia. Helsinki: Maalaiskuntien Liitto.

Stenius, Henrik 1983. Massorganisation och nationell sammanhållning. Sosiologia 20, 112-124.

Stenius, Henrik 1987. Frivilligt, jämlikt, samfällt. Föreningsväsendets utveckling $i$ Finland fram till 1900-talets början med speciell hänsyn till massorganisationsprincipens genombrott (with an English summary 'Voluntarily - Equally - Mutually: A History of Voluntary Associations in Finland until the Early 20th Century, with Special Regard to the Principles of Mass Organization'). Helsingfors: Svenska Litteratursällskapet i Finland.

Sulkunen, Irma 1997. Naisten äänioikeus meillä ja muualla. In Eeva Ahtisaari et al., Yksi kamari - kaksi sukupuolta. Suomen eduskunnan ensimmäiset naiset. Helsinki: Eduskunnan kirjasto, 11-25.

Teljo, Jussi 1949. Suomen valtioelämän murros 1905-1908. Perustuslaillinen senaatti - viimeiset säätyvaltiopäivät - ensimmäinen eduskunta. Porvoo and Helsinki: WSOY. 
Törnudd, Klaus 1968. The Electoral System of Finland. London: Hugh Evelyn. Tuominen, Uuno 1958. Autonomian ajan yksikamarinen eduskunta 19071916. In Suomen kansanedustuslaitoksen historia, vol. 5. Helsinki: Eduskunnan historiakomitea, 163-411.

Viikki, Raimo 1989. Suur-Huittisten historia, vol. 3. Jyväskylä: Gummerus.

Zolberg, Aristide R. 1972. Moments of Madness". Politics and Society 2, 183207. 